\title{
Formate and Oxalate Metabolism in Alcaligenes eutrophus
}

\author{
By CORNELIUS G. FRIEDRICH, ${ }^{1}$ BOTHO BOWIEN ${ }^{1}$ \\ AND BÄRBEL FRIEDRICH ${ }^{2}$ \\ ${ }^{1}$ Institut für Mikrobiologie der Universität Göttingen and ${ }^{2}$ Institut für \\ Mikrobiologie der Gesellschaft für Strahlen- und Umweltforschung $\mathrm{mbH}$, \\ Grisebachstrasse 8, 3400 Göttingen, Federal Republic of Germany
}

(Received 12 December 1978)

\begin{abstract}
Alcaligenes eutrophus strain H16 when grown on formate or oxalate as the sole source of carbon and energy had doubling times between 3.5 and $4.5 \mathrm{~h}$. The respective molar growth yields $\left(Y_{\mathrm{m}}\right)$ were 2.35 and 3.9. During growth on formate or oxalate both a soluble and a membrane-bound formate dehydrogenase were formed. The key enzymes of autotrophic $\mathrm{CO}_{2}$ fixation, ribulose-5-phosphate kinase and ribulosebisphosphate carboxylase, were formed during growth on formate but not on oxalate. Oxalate induced the synthesis of the enzymes of the glycerate pathway. Mutants impaired in autotrophic $\mathrm{CO}_{2}$ fixation but unaffected in the synthesis of the formate dehydrogenases lost their ability to grow on formate but not to grow on oxalate, giving further evidence that formate was assimilated via $\mathrm{CO}_{2}$.
\end{abstract}

\section{INTRODUCTION}

Growth on one-carbon $\left(\mathrm{C}_{1}\right)$ compounds and their metabolism has been intensively investigated with facultative methylotrophic micro-organisms. The ability to utilize $\mathbf{C}_{\mathbf{1}}$ compounds such as methanol, methylamine or formate is distributed over a wide variety of micro-organisms belonging to different taxonomic groups as reviewed by Quayle (1972) and Anthony (1975). Among the phototrophic bacteria, detailed work has been done with Rhodopseudomonas palustris (Stokes \& Hoare, 1969) and Rhodopseudomonas acidophila (Sahm et al., 1976) which grow anaerobically with methanol or formate in the light, and with some Rhodospirillaceae able to grow on methanol (Quayle \& Pfennig, 1975). The information available on the utilization of $\mathrm{C}_{1}$ compounds by aerobic facultative chemolithotrophic bacteria has so far been limited to Thiobacillus novellus (Chandra \& Shethna, 1977), Thiobacillus A2 (Gottschal \& Kuenen, 1977), Paracoccus denitrificans (Cox \& Quayle, 1975) and Hydrogenomonas eutropha Z-1 (Namsaraev et al., 1971). Among anaerobic micro-organisms, some methanogenic bacteria can utilize formate or oxalate for methanogenesis (Dawson \& Allison, 1977; Sineriz \& Wolin, 1977). Micro-organisms able to grow autotrophically on formate can often also grow on oxalate. This is especially true for a large number of the so called 'hydrogen' bacteria (C. G. Friedrich, unpublished results) and other facultative autotrophic micro-organisms. Micro-organisms utilizing $\mathrm{C}_{1}$ compounds have developed different methods of carbon assimilation (Quayle \& Ferenci, 1978). Methylomonas methanolica, Pseudomonas C (Goldberg et al., 1976) and several other strains use the ribulose monophosphate cycle (Quayle, 1972), whereas Pseudomonas AM1 (Quayle, 1972) and Hyphomicrobium X (Harder et al., 1973) use the serine pathway. Thiobacillus novellus (Chandra \& Shethna, 1977) and Pseudomonas oxalaticus oxidize formate to $\mathrm{CO}_{2}$, as Paracoccus denitrificans does with methanol, the $\mathrm{CO}_{2}$ then being assimilated via the Calvin cycle. This type of $\mathrm{C}_{1}$ utilization is therefore designated as autotrophic growth on an 
organic carbon source (Cox \& Quayle, 1975). Among the facultative chemolithoautotrophic micro-organisms, the hydrogen bacteria have not been investigated in detail with respect to their ability to grow on a variety of organic $\mathrm{C}_{1}$ compounds or oxalate. It is, however, of interest to know whether such bacteria can grow on these compounds and, if so, whether they use the enzymes of the Calvin cycle for $\mathrm{CO}_{2}$ fixation or have developed another assimilatory system. The present study was done with one of the best characterized representatives of the hydrogen bacteria, Alcaligenes eutrophus strain H16, to examine these points.

\section{METHODS}

Organisms. Alcaligenes eutrophus strain H16 (ATCC 17699, DSM 428) and mutants derived from it were used throughout this study.

Isolation of mutants. Mutants unable to grow autotrophically with a gas mixture of $\mathrm{H}_{2} / \mathrm{O}_{2} / \mathrm{CO}_{2}(80: 10: 10$, by vol.) were isolated as follows. Cells were mutagenized with sodium nitrite as described by Friedrich \& Schlegel (1975). Since the enrichment of mutants with colistine sulphate usually employed for this organism is ineffective under autotrophic growth conditions, an enrichment procedure with cycloserine was developed that allowed the killing of autotrophically as well as heterotrophically growing cells. Mutagenized cells, grown in a fructose-containing minimal medium for phenotypic expression, were resuspended in minimal medium and incubated overnight under $\mathrm{H}_{2} / \mathrm{O}_{2} / \mathrm{CO}_{2}$. Cycloserine was then added at $1 \mathrm{mg} \mathrm{ml}^{-1}$ and the culture was shaken for $4.5 \mathrm{~h}$. The cells were washed to remove the drug and plated on minimal medium containing $0.004 \%(\mathrm{w} / \mathrm{v})$ sodium pyruvate. Plates were incubated autotrophically. Mutants were identified as pin-point colonies and further characterized by replica-plating and enzyme analysis.

Media and growth conditions. The medium of Schlegel et al. (1961) was used for autotrophic and heterotrophic growth in volumes up to $300 \mathrm{ml}$ in 11 baffled Erlenmeyer flasks. Inocula were grown on the same carbon source as the main culture at $30^{\circ} \mathrm{C}$. For enzyme studies, cells were grown in a medium containing one-fifth of the original buffer concentration and $2 \mathrm{~g} \mathrm{NH}_{4} \mathrm{Cl}$ in 11 . The cells were cultivated in a 121 fermenter (B. Braun, Melsungen, FRG) with a working volume of 101 at $600 \mathrm{rev} \cdot \mathrm{min}^{-1}$ and an aeration rate of $41 \mathrm{~min}^{-1}$. The $\mathrm{pH}$ was kept constant at 7.0 by automatic addition of $5 \mathrm{M}-\mathrm{NaOH}$ or $1.7 \mathrm{M}-\mathrm{H}_{3} \mathrm{PO}_{4}$. When organic acids were used as carbon sources, cells were grown in extended culture using $50 \%(\mathrm{v} / \mathrm{v})$ formic acid or $10 \%(\mathrm{w} / \mathrm{v})$ of other organic acids as titrant for $\mathrm{pH}$ adjustment. For autotrophic growth, the fermenter was gassed with $\mathrm{H}_{2} / \mathrm{O}_{2} / \mathrm{CO}_{2}\left(80: 10: 10\right.$, by vol.) at $850 \mathrm{ml} \mathrm{min}^{-1}$. The growth yield $\left(Y_{8}\right)$ or the molar growth yield $\left(Y_{\mathrm{m}}\right)$ obtained from the different carbon sources was calculated using the equation $Y_{\mathrm{s}}$ or $Y_{\mathrm{m}}=\left(X_{\mathrm{g}}-\right.$ $\left.X_{1}\right) /\left(S_{2}-S_{1}\right)$, where $X$ was the cell concentration (g dry wt) produced and $S$ the amount of substrate $(\mathrm{g}$ or mol) used within a time interval $t_{2}-t_{1}$. Growth was followed turbidimetrically at $436 \mathrm{~nm}$ in a Zeiss PM4 spectrophotometer; $1 \mathrm{~g}$ dry wt $1^{-1}$ corresponded to an $A_{436}$ of $4 \cdot 8$. The substrate consumption of organic acids was calculated from the integrated cycles of a calibrated piston pump coupled to the $\mathrm{pH}$-stat of the fermenter and the concentration of the respective acid.

Substrate shift experiments were conducted in a fermenter with 101 mineral medium containing $0.4 \%$ (w/v) sodium pyruvate, and the $\mathrm{pH}$ controlled by adding $1.7 \mathrm{M}-\mathrm{H}_{3} \mathrm{PO}_{4}$. At an $A_{436}$ of 5.8 pyruvate was exhausted. After another $30 \mathrm{~min}$, a concentrated sodium formate solution was added to the culture to give a final concentration of $20 \mathrm{~mm}$, and the $\mathrm{pH}$ was then kept constant at 7.0 by adding $50 \%(\mathrm{v} / \mathrm{v})$ formic acid. For a substrate change to oxalate, $10 \%(\mathrm{w} / \mathrm{v})$ oxalic acid was added dropwise to the medium which was simultaneously neutralized with a $5 \mathrm{M}-\mathrm{NaOH}$ until a final concentration of $20 \mathrm{~mm}$-sodium oxalate was obtained. During the subsequent oxalate consumption, the $\mathrm{pH}$ was adjusted to 7.0 by adding $10 \%(\mathrm{w} / \mathrm{v})$ oxalic acid. For sampling, cells from $200 \mathrm{ml}$ suspension were collected by centrifuging (yielding about $1 \mathrm{~g}$ wet wt), washed once with $0.9 \%(\mathrm{w} / \mathrm{v})$ sodium chloride and stored at $-20{ }^{\circ} \mathrm{C}$.

Preparation of cell free extracts. Cells (about $1 \mathrm{~g}$ wet wt) were suspended in $5 \mathrm{ml} 50 \mathrm{~mm}$-Tris/ $\mathrm{HCl}$ buffer, $\mathrm{pH} 7.6 ; 0.5 \mathrm{mg}$ deoxyribonuclease $\mathrm{I}$ was then added and the cells were disrupted in a pre-cooled French press at $140 \mathrm{MPa}$. Cell debris was removed by centrifuging at $120000 \mathrm{~g}$ for $60 \mathrm{~min}$ at $4{ }^{\circ} \mathrm{C}$. The supernatant is referred to as the soluble fraction. To stabilize the soluble hydrogenase, a portion of the soluble fraction was treated with ferricyanide at a final concentration of $0.5 \mathrm{~mm}$. The membranes sedimented above the cell debris were scraped off and resuspended in $2.5 \mathrm{ml} 50 \mathrm{~mm}$-potassium phosphate buffer, $\mathrm{pH} \mathrm{7.0}$, and homogenized with a Potter-Elvehjem homogenizer. All extracts were kept at $0^{\circ} \mathrm{C}$.

Enzyme assays. Enzyme activities were determined at $30^{\circ} \mathrm{C}$. Where appropriate, a Zeiss PM4 spectrophotometer fitted with a transmission converter and recorder was used.

The soluble formate dehydrogenase (EC 1.2.1.2) was assayed in $1 \mathrm{ml}$ cuvettes (path length $1 \mathrm{~cm}$ ) con-

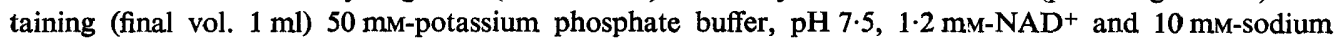
formate. The reaction was initiated by adding the extract and the formation of NADH was recorded at $340 \mathrm{~nm}$. 
The particulate formate dehydrogenase was assayed anaerobically under $\mathrm{N}_{2}$. All solutions except the extract were kept under $\mathrm{N}_{2}$. The reaction mixture contained (final vol. $3.0 \mathrm{ml}$ ) $50 \mathrm{~mm}$-potassium phosphate buffer, pH 7.0, 0.17 mM-methylene blue and 5 to $50 \mu$ l of the membrane fraction. The reaction was initiated by adding $50 \mu 1200 \mathrm{~mm}$-sodium formate and was followed by the decrease in $A_{570}$. The molar extinction coefficient of methylene blue was $13 \cdot 11 \mathrm{mmol}^{-1} \mathrm{~cm}^{-1}$.

Glyoxylate dehydrogenase was determined according to the procedure of Quayle (1966) with modifications. The reaction mixture contained (final vol. $1 \mathrm{ml}$ ) $50 \mathrm{~mm}$-sodium pyrophosphate buffer, pH 9.5, $2 \mathrm{~mm}-$ cysteine, 5 mM-sodium glyoxylate, 0.02 mM-coenzyme A and $0.2 \mathrm{mm-NAD}{ }^{+}$. The reaction was started by adding the enzyme.

Glyoxylate carboligase (EC 4.1.1.47) was assayed in a total volume of $1 \mathrm{ml}$ according to Kaltwasser (1968).

Ribulosebisphosphate carboxylase (EC 4.1.1.39) activity was measured by ribulose bisphosphatedependent incorporation of ${ }^{14} \mathrm{CO}_{2}$ into acid-stable product as described by Bowien et al. (1976). The activity of ribulose-5-phosphate kinase (EC 2.7.1.19) was determined in a two-stage assay by the incorporation of ${ }^{14} \mathrm{CO}_{2}$ into acid-stable product when the ribulose-5-phosphate kinase was coupled to ribulosebisphosphate carboxylase purified from $A$. eutrophus (Bowien et al., 1976). The ribulosebisphophate carboxylase preparation was free of ribulose-5-phosphate kinase activity. The primary reaction mixture contained (in $0 \cdot 25 \mathrm{ml}$ ) $25 \mu \mathrm{mol}$ Tris/ $\mathrm{HCl}$ buffer, $\mathrm{pH} 8 \cdot 0,2 \cdot 5 \mu \mathrm{mol} \mathrm{MgCl}, 1 \cdot 25 \mu \mathrm{mol} \mathrm{ATP,} 0 \cdot 125 \mu \mathrm{mol} \mathrm{NADH}, 0 \cdot 375 \mu \mathrm{mol}$ ribulose 5-phosphate and 5 to $20 \mu \mathrm{l}$ of the soluble fraction. After $5 \mathrm{~min}$ incubation at $30^{\circ} \mathrm{C}$, the reaction was initiated by adding the ribulose 5-phosphate, and $2 \mathrm{~min}$ later it was terminated by heating in a boiling water bath for $1 \mathrm{~min}$. The mixture was then incubated at $30^{\circ} \mathrm{C}$ with $0.1 \mathrm{ml} 0.1 \mathrm{M}$-Tris/ $\mathrm{HCl}$ buffer, $\mathrm{pH} 8 \cdot 0$, containing $1 \mu \mathrm{mol} \mathrm{MgCl}_{2}, 12.5 \mu \mathrm{mol} \mathrm{NaH}{ }^{14} \mathrm{CO}_{3}\left(0.05 \mathrm{Ci} \mathrm{mol}^{-1}\right)$ and 0.02 units of ribulose bisphosphate carboxylase. After $15 \mathrm{~min}, 0.15 \mathrm{ml} 60 \%(\mathrm{w} / \mathrm{v})$ trichloroacetic acid was added and the sample was shaken for $60 \mathrm{~min}$ at room temperature to expel excess ${ }^{14} \mathrm{CO}_{2}$. Acid-stable radioactivity was measured in a Packard liquid scintillation spectrometer.

The soluble hydrogenase (EC 1.12.1.2) was assayed as described by Schneider \& Schlegel (1976); the membrane-bound hydrogenase was measured according to Schink \& Schlegel (1978), but with glucose, glucose oxidase and catalase omitted.

One unit of enzyme activity is defined as $1 \mu \mathrm{mol}$ substrate transformed or product formed min $^{-1}$. Protein was determined by Lowry's method.

\section{RESULTS}

\section{Growth studies}

Alcaligenes eutrophus grew aerobically with formate, oxalate, glyoxylate, glycollate or acetate (in a mineral salts medium) as the sole source of carbon and energy (Table 1). It did not grow on methanol, formaldehyde, methylamine, formamide or ethanol as carbon source. The mean doubling time on formate and oxalate was about $4 \mathrm{~h}$; this was high compared with autotrophic growth on $\mathrm{H}_{2} / \mathrm{CO}_{2}(3 \cdot 2 \mathrm{~h})$ and heterotrophic growth on fructose $(2 \cdot 0 \mathrm{~h})$ or pyruvate $(1 \cdot 5 \mathrm{~h})($ Table 1$)$.

Although cells were grown with formate or oxalate in extended culture, it was not possible to obtain such high cell concentrations as were obtained under autotrophic conditions with $\mathrm{H}_{2} / \mathrm{O}_{2} / \mathrm{CO}_{2}$ or heterotrophic conditions with pyruvate or fructose. Growth ceased at cell concentrations of 0.8 to $1.2 \mathrm{~g}$ dry wt $1^{-1}$. This was thought to be due to $\mathrm{O}_{2}$ starvation. To yield the same cell mass, growth on, e.g., formate requires six to eight times more $\mathrm{O}_{2}$ than growth on fructose. The yields obtained with formate or oxalate were about $50 \mathrm{mg}$ dry wt (g substrate) ${ }^{-1}$. (Low values were expected from such highly oxidized sub-

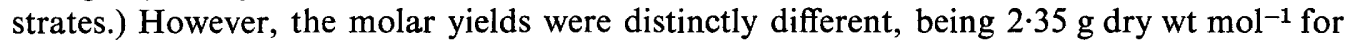
formate and 3.9 for oxalate (Table 1). This was surprising since the energy yield of both substrates is identical and $1 \mathrm{~mol}$ of each substrate yields 1 mol NADH (Blackmore et al., 1968). Formate was utilized with almost $50 \%$ greater efficiency by Paracoccus denitrificans ( $\left.Y_{\mathrm{m}} 3 \cdot 6\right)$ (van Verseveld \& Stouthamer, 1978), by Thiobacillus A2 ( $\left.Y_{\mathrm{m}} 3 \cdot 5\right)$ (Gottschal \& Kuenen, 1977) or by Pseudomonas oxalaticus OX1 ( $\left.Y_{\mathrm{m}} 3.4\right)$; this last strain grew with a similar molar yield on oxalate $\left(Y_{\mathrm{m}} 3 \cdot 8\right)$ (Dijkhuizen et al., 1977) to that of A. eutrophus. 


\section{Table 1. Growth rates and yields of A. eutrophus}

Growth yields [ $Y_{\mathrm{g}}$, expressed as $\mathrm{g}$ dry wt (g substrate) ${ }^{-1}$, and $Y_{\mathrm{m}}$, expressed as $\mathrm{g}$ dry wt (mol substrate $)^{-1}$ ] were determined as described in Methods and are calculated on the basis of free acids.

$\begin{array}{lccc}\text { Substrate } & \begin{array}{c}\text { Doubling } \\ \text { time }(\mathrm{d})\end{array} & Y_{\mathrm{B}} & Y_{\mathrm{m}} \\ \text { Formate } & 4 \cdot 0 & 0.051 & 2 \cdot 35 \\ \text { Oxalate } & 4 \cdot 0 & 0.044 & 3.9 \\ \text { Pyruvate } & 1 \cdot 5 & 0.38 & 33 \cdot 7 \\ \text { Fructose } & 2 \cdot 0 & 0.44 & 79 \cdot 2 \\ \mathrm{H}_{2} / \mathrm{CO}_{2} & 3 \cdot 2 & \mathrm{ND} & \mathrm{ND} \\ \text { Glyoxylate } & 6 \text { to } 9 & 0.083 & 6 \cdot 12 \\ \text { Glycollate } & 3 \cdot 3 & 0.146 & 11.10\end{array}$

ND, Not determined.

Table 2. Activities of energy-generating enzymes of A. eutrophus during growth on different substrates

Cells were grown in a fermenter with a 101 working volume, different sample volumes were taken to yield about $1 \mathrm{~g}$ wet wt cells and enzymes were determined as described in Methods. There was no change in the specific activity of all enzymes measured during the exponential and earlystationary phases caused by nitrogen depletion in the medium. The data presented were obtained from samples of mid-exponential growth.

\begin{tabular}{|c|c|c|c|c|}
\hline \multirow[b]{3}{*}{ Substrate } & \multicolumn{4}{|c|}{ Specific activity [units (mg protein) $)^{-1}$ ] } \\
\hline & \multicolumn{2}{|c|}{ Formate dehydrogenase } & \multicolumn{2}{|c|}{ Hydrogenase } \\
\hline & Soluble & Particulate & Soluble & Particulate \\
\hline Formate & $0 \cdot 245$ & $6 \cdot 128$ & 0.524 & 0.424 \\
\hline Oxalate & $0 \cdot 247$ & $0 \cdot 216$ & 0.008 & 0.025 \\
\hline $\mathrm{H}_{2} / \mathrm{CO}_{2}$ & 0.007 & $0 \cdot 231$ & 0.419 & $0 \cdot 918$ \\
\hline Fructose & 0.003 & 0.028 & 0.108 & $0 \cdot 101$ \\
\hline Pyruvate & 0.002 & $0 \cdot 018$ & 0.003 & 0.003 \\
\hline
\end{tabular}

\section{Enzyme studies}

To elucidate the mode of formate and oxalate utilization, the enzymes of energy generation and carbon assimilation were studied. Alcaligenes eutrophus formed two formate dehydrogenases during growth on formate and oxalate - a soluble formate: $\mathrm{NAD}^{+}$oxidoreductase and a membrane-bound formate:acceptor oxidoreductase. A membrane-bound formate oxidase was reported by Chandra \& Shethna (1975) from Alcaligenes LOX grown on succinate plus formate. The membrane-bound formate dehydrogenase from $A$. eutrophus was routinely assayed anaerobically with methylene blue as electron acceptor. Under the same conditions of growth, both soluble and membrane-bound hydrogenases were formed (Table 2). The hydrogenases apparently resemble the formate dehydrogenases with respect to location and acceptor specificity. It was possible that the formate dehydrogenase activities were identical with the hydrogenase proteins but with a lack of substrate specificity. However, highly purified soluble as well as particulate hydrogenase did not function with formate as substrate. Furthermore, some enzymic properties of the formate dehydrogenases differed significantly from those of the hydrogenases (Y. Aharonowitz \& C. G. Friedrich, unpublished results).

Growth on various carbon and energy sources revealed that the synthesis of the soluble formate dehydrogenase was regulated by induction (Table 2). Both enzymes were formed at a high activity during growth on formate or oxalate. The soluble enzyme was almost absent when fructose, pyruvate or $\mathrm{H}_{2} / \mathrm{CO}_{2}$ served as energy and carbon sources. Also, the expression of the particulate enzyme was markedly decreased except under chemolitho- 
Table 3. Activities of carbon-assimilating enzymes of A. eutrophus during growth on different substrates

Conditions were as described in Table 2.

\begin{tabular}{lcccc} 
& \multicolumn{3}{c}{ Specific activity [units (mg protein) ${ }^{-\mathbf{1}}$ ] } \\
Substrate & $\begin{array}{c}\text { Glyoxylate } \\
\text { carboligase }\end{array}$ & $\begin{array}{c}\text { Glyoxylate } \\
\text { dehydrogenase }\end{array}$ & $\begin{array}{c}\text { Ribulose- } \\
\text { bisphosphate } \\
\text { carboxylase }\end{array}$ & $\begin{array}{c}\text { Ribulose- } \\
\text { 5-phosphate } \\
\text { kinase }\end{array}$ \\
Formate & 0.030 & 0.004 & 0.221 & 0.113 \\
Oxalate & 0.454 & 0.175 & 0.023 & 0.001 \\
$\mathrm{H}_{2} / \mathrm{CO}_{2}$ & 0.018 & 0.002 & 0.263 & 0.211 \\
Fructose & 0.015 & 0.001 & 0.053 & $<0.001$ \\
Pyruvate & 0.009 & 0.004 & $<0.001$ & $<0.001$
\end{tabular}

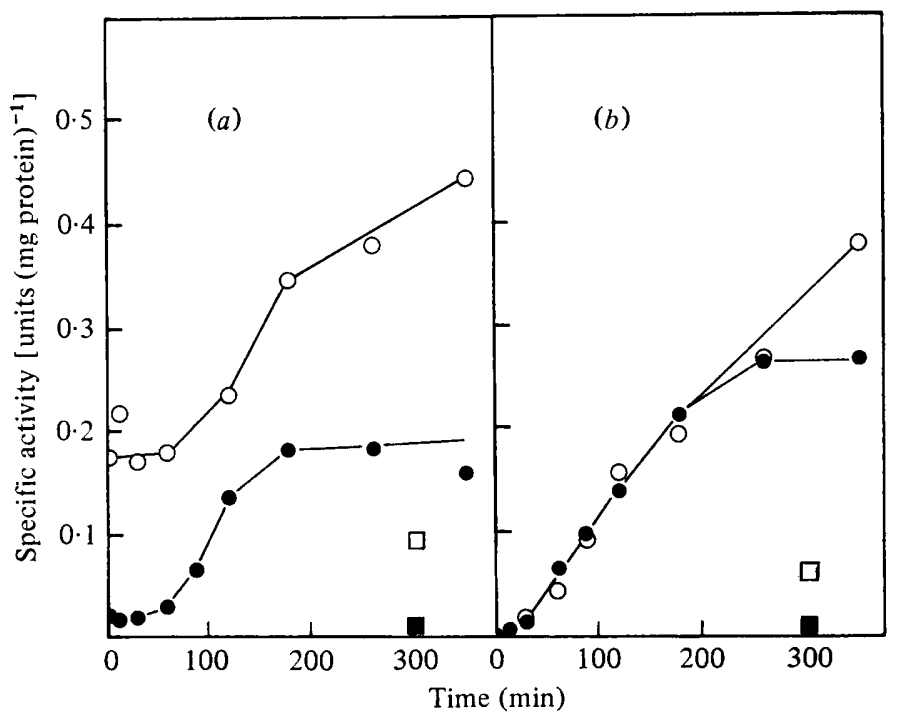

Fig. 1. Formation of energy-generating and carbon-assimilating enzymes of A. eutrophus after a substrate shift from pyruvate to formate. The substrate shift and the determination of the enzyme activity were done as described in Methods. Formate was added at zero time. (a) $\bigcirc$, Membranebound formate dehydrogenase; $\bigcirc$, soluble formate dehydrogenase. $(b) \bigcirc$, Ribulose-5-phosphate kinase; $\bigcirc$, ribulosebisphosphate carboxylase. $\square$ and $\square$ represent chloramphenicol controls for enzymes with open and closed symbols, respectively.

autotrophic conditions. There was no correlation between the formation of hydrogenases and formate dehydrogenases.

Of the various possible carbon-assimilating reactions during growth on formate or oxalate, we decided to follow the activities of ribulose-5-phosphate kinase and ribulosebisphosphate carboxylase and of glyoxylate dehydrogenase and glyoxylate carboligase. Only ribulose-5phosphate kinase and ribulosebisphosphate carboxylase were formed during growth on formate and, as expected, under autotrophic conditions with hydrogen as electron donor. Ribulosebisphosphate carboxylase, however, was also formed with oxalate as carbon source at up to $10 \%$ of the autotrophic level and with fructose at up to $20 \%$. During heterotrophic growth, ribulose-5-phosphate kinase was absent. Glyoxylate dehydrogenase and glyoxylate carboligase were formed exclusively during growth on oxalate (Table 3). Glyoxylate dehydrogenase reacted only with $\mathrm{NAD}^{+}$and not with $\mathrm{NADP}^{+}$as described for the enzyme from Ps. oxalaticus (Quayle, 1966). 


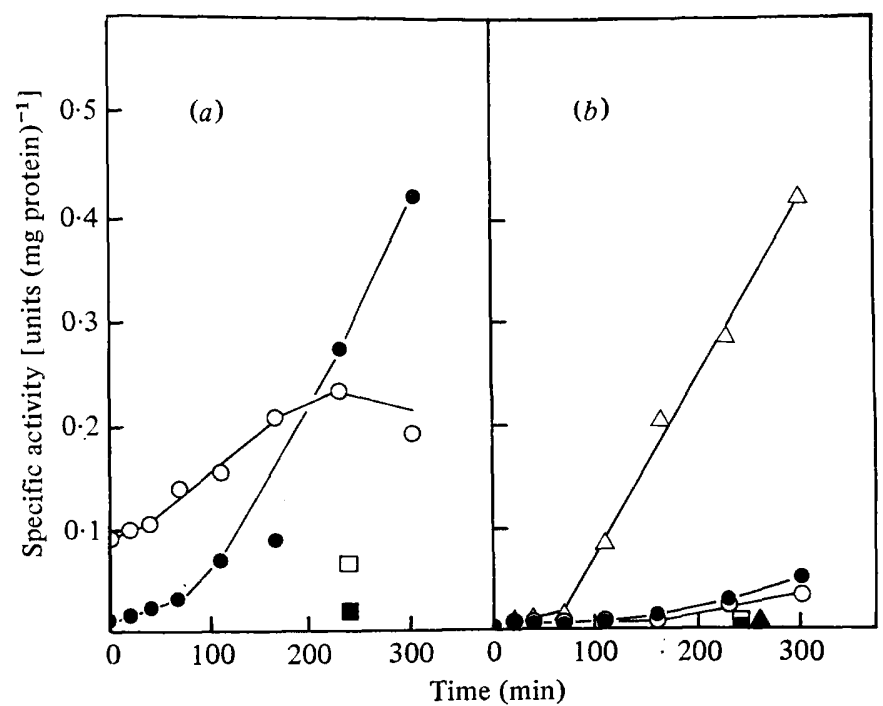

Fig. 2. Formation of energy-generating and carbon-assimilating enzymes of $A$. eutrophus after a substrate shift from pyruvate to oxalate. The substrate shift and enzyme determination were done as described in Methods. Oxalate was added at zero time. (a) $\bigcirc$, Membrane-bound formate dehydrogenase; , soluble formate dehydrogenase. (b) $\bigcirc$, Ribulose-5-phosphate kinase; $\bigcirc$, ribulosebisphosphate carboxylase; $\triangle$, glyoxylate carboligase. $\square$ and $\square$ represent chloramphenicol controls for the enzymes with open and closed symbols, respectively, and $\boldsymbol{\Delta}$ the control for glyoxylate carboligase.

\section{Table 4. Activities of formate dehydrogenases and $\mathrm{CO}_{2}$-assimilating enzymes in mutants of $A$. eutrophus}

Cells were grown in $400 \mathrm{ml}$ minimal medium containing $0.4 \%(\mathrm{w} / \mathrm{v})$ sodium pyruvate stirred magnetically at $30{ }^{\circ} \mathrm{C}$. The pH was kept constant at 7.0 by adding $1 \cdot 7 \mathrm{M}-\mathrm{H}_{3} \mathrm{PO}_{4}$. After growth had ceased, $200 \mathrm{ml}$ of the culture was centrifuged as described in Methods, and sodium formate was added to the remainder to give $20 \mathrm{~mm}$. Incubation was continued for another $4 \mathrm{~h}$ while the $\mathrm{pH}$ was kept at 7.0 by adding $5 \mathrm{M}$-formic acid.

\begin{tabular}{|c|c|c|c|c|c|c|}
\hline \multirow[b]{3}{*}{ Strain } & \multirow{3}{*}{$\begin{array}{c}\text { Relevant } \\
\text { phenotype* }\end{array}$} & \multirow{3}{*}{$\begin{array}{l}\text { Carbon } \\
\text { source }\end{array}$} & \multicolumn{4}{|c|}{ Specific activity [units (mg protein) $)^{-1}$ ] } \\
\hline & & & \multicolumn{2}{|c|}{ Formate dehydrogenase } & \multirow{2}{*}{$\begin{array}{l}\text { Ribulose- } \\
\text { bisphosphate } \\
\text { carboxylase }\end{array}$} & \multirow{2}{*}{$\begin{array}{l}\text { Ribulose- } \\
\text { 5-phosphate } \\
\text { kinase }\end{array}$} \\
\hline & & & Soluble & Particulate & & \\
\hline H16 & $\mathrm{Aut}^{+} \mathbf{H y d}^{+}$ & $\begin{array}{l}\text { Pyruvate } \\
\text { Formate }\end{array}$ & $\begin{array}{l}0.002 \\
0.447\end{array}$ & $\begin{array}{l}0.008 \\
0.244\end{array}$ & $\begin{array}{r}<0.001 \\
0.243\end{array}$ & $\begin{array}{r}<0.001 \\
0.311\end{array}$ \\
\hline HF18 & $\mathrm{Aut}^{+} \mathrm{Hyd}^{-}$ & $\begin{array}{l}\text { Pyruvate } \\
\text { Formate }\end{array}$ & $\begin{array}{l}0.002 \\
0.294\end{array}$ & $\begin{array}{l}0.010 \\
0.066\end{array}$ & $\begin{array}{r}<0.001 \\
0.232\end{array}$ & $\begin{array}{r}<0.001 \\
0.307\end{array}$ \\
\hline HF17 & Aut $^{-} \mathbf{H y d}^{+}$ & $\begin{array}{l}\text { Pyruvate } \\
\text { Formate }\end{array}$ & $\begin{array}{l}0.002 \\
0.047\end{array}$ & $\begin{array}{l}0.013 \\
0.011\end{array}$ & $\begin{array}{l}<0.001 \\
<0.001\end{array}$ & $\begin{array}{l}<0.001 \\
<0.001\end{array}$ \\
\hline
\end{tabular}

* Aut-, Inability to assimilate $\mathrm{CO}_{2}$ via the Calvin cycle; $\mathrm{Hyd}^{-}$, lack of soluble and membrane-bound hydrogenase activity.

\section{Substrate shift and enzyme formation}

From Tables 2 and 3 it is evident that neither the specific energy-generating nor the specific carbon-assimilating enzymes involved in the metabolism of oxalate and formate were present during growth on pyruvate. Bacteria grown on pyruvate were therefore suitable for following enzyme formation after exhaustion of pyruvate in the medium and exposure of the culture to formate or oxalate. A shift from pyruvate to formate caused the immediate formation of ribulose-5-phosphate kinase and ribulosebisphosphate carboxylase. One hour after adding formate, increases in the activity of the soluble and membrane-bound formate 
dehydrogenases were detected. The maximum rates of increase in the specific activities of the enzymes were almost identical (Fig. 1).

During a shift from pyruvate to oxalate, the activities of the same enzymes were followed and, in addition, glyoxylate carboligase was assayed as a specific enzyme of the glycerate pathway. The soluble formate dehydrogenase [the only enzyme for energy generation during growth on oxalate (Blackmore et al., 1968)] and the membrane-bound formate dehydrogenase increased about $1 \mathrm{~h}$ after the substrate change and were synthesized during the following $4 \mathrm{~h}$ (Fig. 2). Glyoxylate carboligase was also formed at a constant rate starting about $1 \mathrm{~h}$ after the introduction of oxalate. As expected, the key enzymes for $\mathrm{CO}_{2}$ fixation (ribulose-5phosphate kinase and ribulosebisphosphate carboxylase) remained at very low specific activities (Fig. $2 b$ ). The increase in enzyme activities after the shifts was due to de novo synthesis since no increase was observed in the presence of chloramphenicol.

\section{Investigation with mutants}

The biochemical data suggested that autotrophic growth on formate was occurring since the key enzymes of $\mathrm{CO}_{2}$ fixation were present at a high activity. This evidence was further supported by experimental results with mutants that had lost the ability to grow autotrophically with $\mathrm{H}_{2}$ as energy source and $\mathrm{CO}_{2}$ as carbon source. Two classes of mutants were characterized: (i) strains lacking the key enzymes of the Calvin cycle (Aut ${ }^{-}$) and (ii) strains lacking the soluble as well as the membrane-bound hydrogenase ( $\left.\mathrm{Hyd}^{-}\right)$. Aut $^{-}$mutants were unable to grow on formate but grew well on oxalate. Hyd- mutants were able to grow on both substrates. Both types of mutants still formed formate dehydrogenases after shifting the cells from pyruvate to formate (Table 4). However, strain HF17 (Aut ${ }^{-}$) did not reveal any activity of ribulosebisphosphate carboxylase or ribulose-5-phosphate kinase, which obviously resulted in the failure to grow on formate.

\section{DISCUSSION}

Alcaligenes eutrophus strain $\mathrm{H} 16$ grew well on formate or oxalate as sole source of carbon and energy. From the data presented here, it is clear that $A$. eutrophus did not assimilate formate directly but first oxidized it to $\mathrm{CO}_{2}$ by the action of two formate dehydrogenases. The soluble enzyme was specifically formed when formate was introduced into the medium and, being linked to $\mathrm{NAD}^{+}$, it enabled the cell to derive energy from formate. The particulate enzyme was unspecifically formed and appeared under different conditions of growth at certain levels; thus its physiological function as well as its physiological electron acceptors remain to be elucidated. That the $\mathrm{CO}_{2}$ derived from formate was fixed via the Calvin cycle is indicated by two results: (i) the appearance of ribulose-5-phosphate kinase and ribulosebisphosphate earboxylase during growth on formate and also on the introduction of formate into the medium; and (ii) mutants unable to fix $\mathrm{CO}_{2}$ via the Calvin cycle were also unable to grow on formate.

The multivalent use of the term 'autotrophy' has led to a generally accepted definition which restricts its use to the carbon source regardless of where the energy comes from: an autotrophic organism is able to derive cellular carbon from $\mathrm{CO}_{2}$ as the major carbon source. Since $A$. eutrophus derived its carbon from $\mathrm{CO}_{2}$ during growth on formate, by this definition it grows autotrophically on this substrate.

Growth on oxalate was heterotrophic since mutants unable to grow autotrophically grew on oxalate as well as the wild-type. Furthermore, the key enzymes for $\mathrm{CO}_{2}$ fixation could be detected neither in oxalate-grown cells nor in those from the induction experiment with oxalate.

Alcaligenes eutrophus therefore utilized formate like a number of other bacteria, e.g. Ps. oxalaticus (Quayle \& Keech, 1959), Pc. denitrificans (Cox \& Quayle, 1975), Thiobacillus A2 (Gottschal \& Kuenen, 1977) and T. novellus (Chandra \& Shethna, 1977), another facultative chemolithoautotrophic organism that can also grow on oxalate. A wide variety of 
bacteria can utilize formate and two mechanisms of utilization have been described (Quayle, 1972; Quayle \& Ferenci, 1978): (i) the reduction of formate and subsequent assimilation of formaldehyde via the serine pathway and (ii) the oxidation of formate and assimilation of $\mathrm{CO}_{2}$. With a few exceptions, bacteria oxidize formate to $\mathrm{CO}_{2}$ and, except for the methanogenic bacteria, assimilate $\mathrm{CO}_{2}$ via the Calvin cycle. Among these organisms only A. eutrophus, $P c$. denitrificans, $T$. novellus and Thiobacillus A2 are facultative chemolithoautotrophs. The questions of whether the ability to utilize formate was gained by autotrophic microorganisms and whether the ability to use another energy source like hydrogen or thiosulphate was lost by certain organisms during evolution remain to be answered.

We are grateful to Dr K. Schneider for the generous gift of purified hydrogenase.

\section{REFERENCES}

ANTHONY, C. (1975). The biochemistry of methylotrophic microorganisms. Science Progress 62, 167-206.

Blackmore, M. A., Quayle, J. R. \& Walker, 1. O. (1968). Choice between autotrophy and heterotrophy in Pseudomonas oxalaticus: utilization of oxalate by cells after adaptation from growth on formate to growth on oxalate. Biochemical Journal 107, 699-704.

Bowien, B., Mayer, F., Codd, G. A. \& Schlegel, H. G. (1976). Purification, some properties and quaternary structure of the D-ribulose 1,5-diphosphate carboxylase of Alcaligenes eutrophus. Archives of Microbiology 110, 157-166.

Chandra, T.S. \& Shethna, Y. I. (1975). Oxalate and formate metabolism in Alcaligenes and Pseudomonas species. Antonie van Leeuwenhoek 41, 465-477.

Chandra, T. S. \& Shethna, Y. I. (1977). Oxalate, formate, formamide, and methanol metabolism in Thiobacillus novellus. Journal of Bacteriology 131, 389-398.

Cox, R. B. \& QuAYLE, J. R. (1975). The autotrophic growth of Micrococcus denitrificans on methanol. Biochemical Journal 150, 569-571.

Dawson, K. A. \& Allison, M. J. (1977). Anaerobic oxalate degradation and methanogenesis by enrichment culture of rumen bacteria. Abstracts of the Annual Meeting of the American Society for Microbiology, p. 180.

DiJkhuizen, L., Wiersma, M. \& HARdeR, W. (1977). Energy production and growth of Pseudomonas oxalaticus OX1 on oxalate and formate. Archives of Microbiology 115, 229-236.

FrIedrich, B. \& Schlegel, H. G. (1975). Aromatic amino acid biosynthesis in Alcaligenes eutrophus H16. II. The isolation and characterization of mutants auxotrophic for phenylalanine and tyrosine. Archives of Microbiology 103, 141-149.

Goldberg, I., Rock, J. S., Ben-Bassat, A. \& MATEles, R. I. (1976). Bacterial yields on methanol, methylamine, formaldehyde, and formate. Biotechnology and Bioengineering 18, 16571668.

Gottschal, J. C. \& Kunenen, J. G. (1977). Growth of Thiobacillus A2 on mixtures of thiosulfate and formate. Proceedings of the Society for General Microbiology 4, 74-75.

Harder, W., ATTwood, M. M. \& Quayle, J. R. (1973). Methanol assimilation by Hyphomicrobium sp. Journal of General Microbiology 78, 155-163.

Kaltwasser, H. (1968). Harnsäureabbau und Biosynthese der Enzyme Uricase, Glyoxylatcarbo- ligase und Urease bei Hydrogenomonas H16. I. Bildung von Glyoxylatcarboligase und DGlycerat-3-Dehydrogenase. Archiv für Mikrobiologie 64, 71-84.

Namsaraev, B. B., Nozhevnikova, A. N. \& ZAVARZIN, G. A. (1971). Utilization of formic acid by hydrogen bacteria. Mikrobiologiya (English translation) 40, 772-776.

QUAYLE, J. R. (1966). Glyoxylate dehydrogenase. Methods in Enzymology 9, 342-346.

QUAYLE, J. R. (1972). The metabolism of one-carbon compounds by microorganisms. Advances in Microbial Physiology 7, 119-203.

QuAYle, J. R. \& FeRENCI, T. (1978). Evolutionary aspects of autotrophy. Microbiological Reviews 42, 251-773.

Quayle, J. R. \& Keech, D. B. (1959). Carbon assimilation by Pseudomonas oxalaticus (OX 1). I. Formate and carbon dioxide utilization during growth on formate. Biochemical Journal 72, 623630.

Quayle, J. R. \& Pfennig, N. (1975). Utilization of methanol by Rhodospirillaceae. Archives of Microbiology 102, 193-198.

SAHM, H., CoX, R. B. \& Quayle, J. R. (1976). Metabolism of methanol by Rhodopseudomonas acidophila. Journal of General Microbiology 94, 313-322.

Schink, B. \& Schlegel, H. G. (1978). Hydrogen metabolism in aerobic hydrogen oxidizing bacteria. Biochimie 60, 297-305.

Schlegel, H. G., Kaltwasser, H. \& Gotrschalk, G. (1961). Ein Submersverfahern zur Kultur wasserstoffoxidierender Bakterien: Wachstumsphysiologische Untersuchungen. Archiv für Mikrobiologie 38, 209-222.

Schneider, K. \& Schlegel, H. G. (1976). Purification and properties of soluble hydrogenase from Alcaligenes eutrophus H16. Biochimica et biophysica acta 452, 66-80.

SinerIz, F. \& Wolin, M. J. (1977). Continuous culture of methanogenic bacteria in a formate mineral medium. Abstracts of the Annual Meeting of the American Society for Microbiology, p. 252.

Stokes, J. E. \& Hoare, D. S. (1969). Reductive pentose cycle and formate assimilation in Rhodopseudomonas palustris. Journal of Bacteriology 100, 890-894.

VAN VERSEVELD, H. W. \& Stouthamer, A. H. (1978). Growth yields and the efficiency of oxidative phosphorylation during autotrophic growth of Paracoccus denitrificans on methanol and formate. Archives of Microbiology 118, 21-26. 